\title{
Problems and Countermeasures of Entrepreneurship Education in Colleges and Universities
}

\author{
Siyu Feng \\ College of Food Science and Pharmacy, Xinjiang Agricultural University, Urumqi, Xinjiang 830052, China
}

\begin{abstract}
Since 1980s, entrepreneurship education has become an important part of university education in the world. In the United States, entrepreneurship education has a history of more than 60 years. Under the good social foundation and strong social support system, a perfect entrepreneurship education system has been formed. College students' entrepreneurship has become one of the direct driving forces of American economy. Under the background of "One Belt and One Road", China's trade goes to the international market, and at the same time, the allocation quality and value of resources in the Chinese market are improved. As a result, there are a lot of demands and opportunities for innovation and entrepreneurship in the Chinese market. The contemporary college students have strong sense of innovation and entrepreneurship. With the transformation and upgrading of Chinese industry, the era of knowledge economy driven by innovation driven economic development has come, college students are not only the main body of the future Chinese population, but also the new force to promote the "Chinese dream" of innovation and entrepreneurship. At present, China's existing education system lacks the cultivation of students' entrepreneurial spirit and skills, and the popularity of entrepreneurship education in universities is low.
\end{abstract}

\section{Keywords}

entrepreneurship education; practice platform; curriculum development; training mode

\section{高校创业教育存在的问题及对策}

\section{冯思豫}

新疆农业大学食品科学与药学学院, 中国・新疆 乌鲁木齐 830052

\section{摘 要}

20 世纪 80 年代以来，创业教育在全球已成为大学教育的重要组成部分。在美国，创业教育已经有 60 多年的历史，在良好的 社会基础和有力的社会支持体系下，已经形成完善的创业教育体系，大学生创业已成为美国经济直接驱动力之一。在 “一带 一路” 大背景下中国贸易走向了国际市场，同时让中国市场资源的配置质量、价值得到提升，使中国市场中出现了大量创新 创业需求与机会。当代大学生群体具有较强的创新创业意识, 伴随着中国产业转型升级, 创新驱动经济发展的知识经济时代 已经到来, 大学生不仅是未来中国人口的主体, 更是推动创新创业 “中国梦” 的生力军。目前, 中国现有的教育体系缺乏对 学生创业创新精神和技能的培养, 大学创业教育普及程度低。

\author{
关键词 \\ 创业教育; 实践平台; 课程设置; 培养模式
}

\section{1 引言}

2020 年宁德鹏的不同类型高校大学生创业行为及其影响 因素的差异特征研究发现, 在创业教育各细分维度的现状与 差异上，八类学生对创业教育的评价都显示出高度的统一： 学校因素 $>$ 个人因素 ${ }^{[4]}$ 。因此, 学校在创新创业教育中扮演 着重要角色, 当前推动中国大学创业教育发展的两个重心: 一是建设合理的创业教育课程以及包括创业课程、创业研究、 创业论坛、创业竞赛和创业者联盟五个模块的创业教育体系; 二是组织培养优秀的创业教育师资, 通过培训、聘请既有实 际管理工作经验又有一定管理理论修养的企业家、咨询师、
创业投资家、政府官员等担任兼职讲师等形式，加强创业教 育师资队伍的建设 ${ }^{[1]}$ 。

\section{2 学校创业教育现状}

2015 年 12 月, 教育部下发通知要求所有高校从 2016 年 起都要开设创新创业教育课程, 随后, 各高校纷纷开设了创 业教育课, 以 “必修课、记学分” 的形式纳入常规课程体系 之内, 并取得了初步成效 ${ }^{[3]}$ 。但由于在创新教育领域中国整 体起步较晚, 开设时间较短, 开设经验不足, 故存在一些问题, 如创业通识教育与专业教育难以有机融合、校外校内产教难 
以融合, 创业教育流于形式无法形成系统性闭环等。同时, 许多高校还存在专职师资力量不足的现象等。这在一定程度 上降低了创业教育的实效性 ${ }^{[5]}$ 。

\section{3 大学生创业教育存在问题}

\section{1 高校对培养模式的迷茫}

在学生已经形成了自己的认知以后, 传统的 “灌输式” 教育模式会束缚学生创造力、创新力等高素质人才所必需品 质的发展。中国创新创业培养仍然处于上升发展阶段, 部分 高校虽然已经对创新精神教育有所领悟, 但缺乏有效的实践 证明, 即使加强了创新创业教育, 但在课程设置以及内容修 改方面存在滞后, 或是没有立竿见影的效果 ${ }^{[2]}$ 。

\section{2 社会思潮对大学生创业教育的影响}

从社会思潮对大学生创业价值观的影响来看, 产生较大 影响的不良社会思潮有历史虚无主义、拜金主义、新自由主义、 个人主义等社会思潮, 一定程度上对大学生创业的可持续发 展形成某些不利影响。这些不良社会思潮相互交叉影响着大 学生创业价值观, 亟待加以正确引导 ${ }^{[6]}$ 。

\section{3 学习课程设置不合理}

首先, 高校的诸多专业课缺乏交汇融合, 通常都是 “学 一科, 考一科” 的应试学习方式, 使学生无法重视自己所学 的知识, 更不必说融会贯通并付诸实践创新。

其次, 专业课程缺乏引导以及实践, 学习内容过于分散, 使许多学生对自己的发展方向感到迷茫。

最后, 高校为学生提供发展创新能力的平台较少, 学生 无法从实践中找到自己的发展方向, 连目标都不够明确, 更 无需谈创新创业。

\section{4 历史政策遗留因素的制约}

中国的高校毕业生就业相关政策从最初的 “统包统配” 到后来的 “双向选择, 自主择业” 的市场依赖调控机制, 已 经实行了很长的时间。“找个稳定工作”的传统思想使许多 高校在校生不会去考虑创新创业的问题, 他们会更偏爱像公 务员这样稳定的 “铁饭碗”。创新创业意识的缺乏, 很可能 导致高校在校生错失良好的发展机会, 令人惋惜 ${ }^{[7]}$ 。

\section{4 大学生创业教育对策}

\section{1 从社会思潮方面转变大学生对 “创业教育” 的认识}

从整体上转变大学生对 “创业教育” 本质的认识, 将
创业教育内化为学生提升自身素质的一个重要指标, 而非 “追求经济利益”的助推器。对于各类院校学生要进行思 想境界大提升教育活动, 教育各类型高校学生, 创业动机 应以社会贡献实现自我等正能量追求为首选, 而不是经济 追求。社会要对创业失败者有更大的包容度, 营造良好的 创新创业文化和氛围; 高校要努力承担创业人才培养的主 阵地作用, 将切实提升学生的创新创业素养作为人才培养 的最终目标。

\section{2 打造高校创业教育的主阵地、主战场}

\subsection{1 完善创业课程体系}

根据不同年级开设通识课程、专业课程并纳入选修课程 和必修课程学分管理。是将创业政策的宣传解读融入《形势 与政策》课程, 定期向学生宣传解读有关大学生创业的创业 政策, 让学生看得到创业政策所释放的红利。

\subsection{2 积极搭建创新实践的平台}

一是促进 “双创学院”地位合法化。在各二级学院设立 “创 业墙” ，定期发布解读创业政策以及校友的成功创业故事。

二是举办一些科研创新的讲座, 学院牵头寻找有能力、 有经验的成功领导团队, 帮助有意愿的同学着手进行创新计 划, 并提供必要的指导。

三是积极举办具有创新创业性质的比赛, 进行校内选拔, 进而参加省级、国家级的比赛, 让学生学习与适应 “分析问题一 构建思路一实施运作一验证方案一反馈修改” 的螺旋式思维

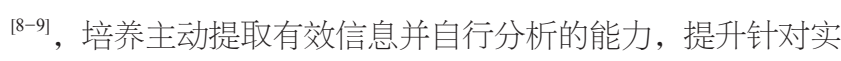
际问题的处理能力以及创新能力。

四是在校内建立起跨学科的新型组织机构, 将不同专业 与发展方向的人才聚集起来, 组建跨学科项目的合作团队, 探究解决跨学科专业的复杂问题, 提升学生的创新精神与能

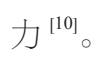

\section{2 .3 校企合作常态化}

不定期邀请小微企业、初创企业代表到学校举办创业论 坛, 内容形式可以生动多样化, 以企业生动的成功创业故事 感染大学生, 激发大学生的创业激情, 创业意向, 以这些创 业代表对创业政策的解读与对国家税收政策的受惠激发大学 生的创业政策满意度。

\subsection{4 实现 “强强联合”}

在校际合作层面, 强强联合、优势互补、以强补弱、取 
长补短以达到共同整体提升创业动机、创业激情、创业意向、 创业政策满意度，助推创业行为发生。

一是 “强强联合”, 共同提升创业动机和创业政策满意度。 由创业政策满意度最强的师范类、医学类、农林类和其他类 型院校分享创业政策的感受，同时由创业动机最强的财经类、 理工类、综合类和其他类高校学生代表分享其创业动机和追 求。其他因素, 以此办法执行。

二是可邀请 “创业基因满满” 的财经类院校学生代表前 来学习和交流以改善自身的不足 ${ }^{[1]}$ 。

\section{5 创新创业发展末来}

从 2017 年 2 月开始, 教育部先后形成了 “复旦共识” “天 大行动” 和 “北京指南”, 发布《关于开展新工科研究与实 践的通知》, 开拓了工科教育改革新路径, 搭建起了新工科 建设的基本框架。在此背景下，提升高校大学生创新创业的 能力, 需要将重点放在 “新” 上。《统筹推进世界一流大学 和一流学科建设总体方案》中指出, 要培养具有历史使命感 和社会责任心、富有创新精神和实践能力的各类创新型、应 用型、复合型优秀人才。要及时掌握学生新的需求, 坚持以 学生为中心的教学理念, 对教学方法进行改进, 增大学生的 选择空间，进一步加大搭建创新创业实践平台的投入，推动 产学研的紧密结合, 探索建立企业与学校共建共管的产业化 学院, 促进教学、培训、研究一体化发展。为满足未来新兴 产业和新经济的需要, 仍需努力探索, 促进高校教育改革, 为中国产业发展和国际竞争提供智力和人才支撑 ${ }^{[7]}$ 。

\section{参考文献}

[1] 木志荣. 我国大学生创业教育模式探讨 [J]. 高等教育研究, 2006 (11):79-84.

[2] 房国忠, 刘宏妍. 美国大学生创业教育模式及其启示 [J]. 外国教育 研究 ,2006(12):41-44.

[3] 许海媚. “一带一路” 发展背景下大学生创新创业存在的机遇及 挑战研究 [J]. 法制博览, 2020(24):229-230.

[4] 宁德鹏. 不同类型高校大学生创业行为及其影响因素的差异特 征研究——基于百所高校大样本的实证考察 [J/OL]. 广西社会 科学 ,2020(05):178-184[2020-08-27].http://kns.cnki.net/kcms/ detail/45.1185.C.20200817.1727.060.html].

[5] 沈丽丹, 郁晓昕. “互联网 +”环境下大学生创业意愿影响因素及 孵化对策研究 [J]. 上海管理科学, 2020(04):102-109.

[6] 苏海泉, 王国辉. 社会思潮对大学生创业价值观的影响及教育 [J]. 当代青年研究 ,2019(01):57-61.

[7] 袁嵩, 黄新宇, 陆佳金金. 大学生创新创业能力培养探索 [J]. 教育教 学论坛, 2020(35): 75-76.

[8] 张永强,陈捷, 贺普峥. 创新创业教育视域下高校计算机类学生创 新能力培养路径 [J]. 教育评论, 2018(05):79-83.

[9] 国务院印发《统筹推进世界一流大学和一流学科建设总体方案》 [J]. 西部素质教育, 2015(18):127.

[10] 宁德鹏, 葛宝山. 创业教育对创业行为的影响机理研究 [J]. 中国高 等教育, 2017(10):55-57.

[11] 朱艺璇, 朱珠. 高校思政教育促进大学生创新创业教育的路径研 究 [J]. 科教文汇 (上旬刊),2020(08):51-52. 